the monument, the Director-General of the Army Medical Department, as Chairman of the Monument Committee, delivered the following address :-

"May it please your Royal Highness,-During the war with Russia in 1854,1855 , and 1856 , her Majesty's army lost by death fifty-four officers of the medical department, who were serving in the campaign, and six physicians and surgeons attached for duty to, but not commissioned officers of, the army. The greater part of these gentlemen died from disease contracted in the discharge of their duties, or broke down under the enormous pressure of professional work which was entailed upon them by the sickly condition of the force in the winter of 1854-5. On the conclusion of the war it appeared desirable that some tribute should be paid to the memory of those who had thus sacrificed their lives in affording professional aid to the soldiers who were gallantly fighting their country's battles, and a subscription was commenced for that purpose, which was contributed to not only by the officers of the medical department, but also by other officers of all ranks and by many civilians. Various causes combined to delay the com pletion of the scheme thus laudably commenced, but at length the Committee to whom was entrusted its execution, in the beginning of the present year obtaned from Mr. T. Hayter Lewis, F.S.A. a design for a monument which seemed to them well calculated to effect the object in view, and to hand down to succeeding generations the memory of those medical officers who had perished in the service of their country in that war. The Committee have ventured to solicit your Royal Highness to inaugurate the work by laying the foundation-stone from a feeling that such an act on the part of your Royal Highness will be appreciated by the officers of the Army Medical Department, as a tribute to the memory of their deceased comrades, and that the interest shown by your Royal Highness in thus commemorating the services of those who have fallen at their posts in the discharge of arduous and important duties cannot fail to prove a stimulus in future to us and our successors, zealously, faithfully, and fearlessly to discharge those duties which may fall to be performed in the service of our sovereign and for the honour of our country."

The Prince responded by an address, which was so clearly and distinctly delivered that it was not only heard by the officials by whom he was immediately surrounded, but was plainly audible by the visitors within that part of the enclosure which was in front of him. He alluded with much feeling to the services which had been rendered by the medical officers to the army in the Crimea, and to the gratification he felt in being able to join in paying a tribute to the memory of those who had fallen in the performance of their duties by thus laying the foundation-stone of the monument. He said that the site of the monument was one of deep interest to him, for it was close to that great hospital for the sick and wounded returning from foreign stations, the construction of which his revered father had so anxiously watched, and in which the Queen still felt so much concern. He added also that the position seemed to him the more appropriate, inasmuch as the Army Medical School, which was designed to train young medical officers before entering the army in the special duties they would afterwards have to perform in its ranks, was now established at Netley. These gentlemen would have con stantly before them this monument raised to commemorate the professional devotion of their predecessors, whose examples conld not fail to exert a worthy influence upon their own careers in the service of their country. After the Prince's address, and a prayer had been said by the Chaplain, the stone was laid with the usual forms, the National Anthem was played by the band, and the ceremony terminated.

The Prince of Wales subsequently visited the wards of the hospital, and particularly inspected a number of wounded soldiers who had lately returned from New Zealand. He addressed some kind remarks to these invalids, who were drawn up in line in one of the corridors of the hospital. For one man who had lost a leg. and who seemed to support himself with some little difficulty on his crutches, he desired a chair to be brought. To another, a sergeant of Artillery, who was particularly pointed out to him, the Prince said he was glad to hear a pension and gratuity had been awarded to him for his conduct in the field. This sergeant had lost an arm in action, but was noticed for the particular bravery which he had displayed on an occasion when the Assistant-Surgeon of his battery also gained for himself the Victoria Cross. After leaving the wards the Prince visited the lecture-room, hygienic laboratory, microscopical, and other rooms of the Army Medical School.
The officers of the medical staff were afterwards honoured by the presence of their Royal Highnesses, and a select party of distinguished visitors, at a luncheon which was served in their mess-room.

\section{THE WOUNDED GUARDSMAN.}

THE following letter appeared in The Times of Wednesday last :-

$$
\text { "To the Editor of The Times. }
$$

"Sir,-Since you did me the favour to insert my last communication with reference to the actual condition of Private Cooper of the Coldstream Guards, I have continued to receive so many kind inquiries from different parts of the kingdom respecting him, many of which I have not been able to reply to, that 1 would ask the favour of your allowing me to state through your columns that the poor fellow continues to progress favourably, although the bullet, having fallen back into the cavity of the chest, has not been capable of detection. I am happy to say that 1 still entertain fair hopes of his future recovery on account of his constitutional powers.

"The writer of the paragraph relative to the sad accident, which appeared as an extract from a medical journal in your paper of Saturday last, would seem to maintain the propriety of a practice not sanctioned by the general experience of military surgeons, and I therefore solicit space for a very few remarks regarding it. When a bullet lies near the surface of the body, and within reach of the surgeon, after having penetrated one of the great cavities of the body, the sooner it is extracted the better ; its removal can do no harm, and must in general add to the chances of recovery. Whether in this particular instance the circumstances were such as to render some delay desirable I do not wish to decide; I feel certain that all must have been done which the most anxious regard for the sufferer could dictate. I regret, therefore, the unusual style of the remarks applied to myself, and that they should have found admission into the columns of The Times.

$$
\begin{gathered}
\text { "I have the honour to be, Sir, your obedient servant, } \\
\text { "Surgeon-Major, WYatdstream Guards." }
\end{gathered}
$$

* Mr. Wyatt may rest assured that his regret cannot exceed ours at finding ourselves compelled to notice in an "unusual style" the sad want of taste which he had displayed. Our remarks were but the reflection of a very strong and general feeling in which, we have the best reasons for knowing, Mr. Wyatt's brother officers shared especially. We quite agree with Mr. Wyatt that "the sooner a bullet is extracted the better," but with the proviso that the process of removal does not kill the patient. It is pretty evident from the fact of the bullet having fallen back in to the chest, that, although wedged, as was described, between the ribs, its main bulk must have been lodged on the internal aspect of the thorax. Now, although, according to Mr. Wyatt's dictum, "its removal can do no harm," we must be permitted to doubt whether an operation which would probably necessitate, besides free section of soft tissues, excision of some part of a rib, can be looked upon as so innocuous in the case of a patient who is hovering between life and death.-ED. L.

\section{MILITIA SURGEONS.}

THE following remarks, from the pen of a Militia Surgeon of great experience, are entitled to consideration :-

Ever since the disembodiment of the militia regiments in 1856 , militia surgeons have in vain been endeavouring to obtain that justice which they feel themselves entitled to - viz., that they should be placed on the permanent staff of their regiments when disembodied, which up to the year 1829 , when the militia staff ceased to be kept up in its full strength, had been the case. During the second embodiment of the militia regiments (from 1857 to 1860 ), a Royal Commission sat, and reported early in 1859 that " they are precluded by the instructions they had received from her Majesty, through the Secretary of State for War, from considering the question of placing 